\title{
НЕГАТОРНЫЙ ИСК КАК ОДИН ИЗ СПОСОБОВ ГРАЖДАНСКО-ПРАВОВОЙ ЗАЩИТЫ ПРАВА СОБСТВЕННОСТИ НА ЗЕМЛЮ
}

\author{
(c) 2018 Меденцева Евгения Владимировна \\ заведующий кафедрой правового обеспечения экономической деятельности \\ Самарский государственный экономический университет \\ 443090, г. Самара, ул. Советской Армии, 141 \\ (c) 2018 Подусовская Виктория Вадимовна \\ помощник судьи Самарского областного суда \\ 443099, г. Самара, ул. Куйбышева, д. 60 \\ E-mail: v-podusovskaya@mail.ru
}

В статье рассматривается один из классических способов защиты нарушенного права собственности на земельный участок - негаторный иск. Приводятся основания применения негаторной защиты, а также обязательные условия, в отсутствие которых лицо, право собственности которого в отношении земельного участка нарушено, не сможет воспользоваться данным способом защиты. По общему правилу негаторный иск вправе предъявить только собственник или титульный владелец индивидуально-определенной вещи. Для исследования возможности использования негаторной защиты в статье в качестве примеров, иллюстрирующих выводы и заключения, приводятся судебные акты, составляющие практику по рассматриваемому вопросу.

Ключевые слова: право собственности на землю; титульный владелец; негаторный иск; превентивный иск.

На сегодняшний день нормы действующего законодательства содержат определенные гражданско-правовые меры, направленные на эффективную защиту имущественных прав. Но, несмотря на созданную законодателем систему защитных мер, она не может предотвратить нарушение имущественных прав. Анализ судебной практики позволяет прийти к выводу, что особое место среди правонарушений занимают нарушения права собственности в отношении земельных участков, которые не связаны с лишением владения землей. При этом в целях защиты нарушенного права собственности на земельный участок используют такой гражданско-правовой способ защиты как негаторный иск.

Т.П. Подшивалов в результате размышлений относительно способов защиты прав, используемых в зависимости от того, какое из триады полномочий собственности нарушено, пришел к выводу, что негаторный иск используется в качестве защиты в том случае, если имеется препятствие в пользовании вещью, поскольку при нарушении правомочия владения используется такой способ защиты права, как виндикационный иск, а при оспаривании правомочия распоряжения - иск о признании права собственности $[1$, с. 52].
Данное утверждение не бесспорно, поскольку правомочие распоряжения, заключающееся в том, что собственник вследствие возникших по причине совершения третьим лицом противоправных действий (бездействия) не имеет возможности произвести отчуждение данного имущества, путем заключения договора купли-продажи или дарения, также может быть защищено путем предъявления негаторного требования.

В настоящее время понятие негаторного иска в Гражданском кодексе РФ выражено следующей законодательной формулой: «Собственник может требовать устранения всяких нарушений его права, хотя бы эти нарушения и не были соединены с лишением владения» $[2$, ст.304]. Законодатель определил, что негаторный иск представляет собой требование, не основанное на договоре, владеющего вещью собственника к лицу, которое своими действиями (бездействием) чинит собственнику препятствия в пользовании принадлежащей ему вещью, об устранении таких препятствий, которые фактически нарушают его правомочия по пользованию и распоряжению находящимся у него в собственности имуществом.

Особенность применения негаторного иска 
в ходе защиты права собственности обусловлена абсолютным характером защищаемого права, что выражается в том, что негаторный иск вправе подавать только собственник, а также титульный владелец индивидуально-определенной вещи, о чем указано в ст. 305 ГК РФ[2, ст.305]. Кроме того, совершенное третьим лицом противоправное действие в отношении вещи, принадлежащей собственнику, титульному владельцу, по сути должно препятствовать собственнику или законному владельцу в реализации принадлежащего ему права пользования указанной вещью, и не должно быть соединено с лишением владения вещью. В противном случае, собственник сможет защитить свои права в результате виндикации, но не предъявления негаторного иска.

Следовательно, воспользоваться таким способом защиты нарушенного права собственности, как негаторный иск, может только владеющий собственник или титульный владелец и только в том случае, если нарушение его права собственности не привело к прекращению владения принадлежащей ему индивидуальноопределенной вещью.

Данный вывод подтверждается следующим примером из судебной практики.

Гражданин (Ч.В.) обратился в суд с иском к Ф.О., кадастровому инженеру 3., о признании недействительными результатов кадастровых работ, исключении из государственного кадастра недвижимости сведений о местоположении границы земельного участка.

В обоснование заявленных требований истец указал, что у него в пользовании находится здание дома связи и земельный участок, необходимый для эксплуатации этого здания.

Ответчик О. без каких-либо оснований, передвинул забор между земельными участками домов в сторону дома Ч.В. на несколько метров, самовольно изменив смежную границу между двумя земельными участками, в результате чего часть плодовых кустарников Ч.В. оказалась на территории, которую О. огородил. Земельные участки, на которых расположены дома, разделял установленный по фактическому землепользованию забор.

После проведения кадастровых работ в отношении земельного участка ответчика, площадь его земельного участка увеличилась, в том числе за счет площади земельного участка, используемого Ч.В. и необходимого для полноценной эксплуатации здания дома связи. Истец полагает, что кадастровый инженер 3. при подготовке межевого плана нарушила правила межевания, что привело к захвату свободной территории в дополнение к участку ответчика.

В иске указано, что в результате действий ответчиков нарушено право Ч.В. на формирование земельного участка под объектом недвижимости, который находится в собственности Ч.В., и дальнейшее приобретения права собственности на земельный участок. О нарушении своих прав Ч.В. стало известно в тот момент, когда ответчиком О. осуществлялся перенос забора. Сформировать земельный участок для эксплуатации дома связи истец не имеет возможности, поскольку проектируемая схема расположения земельного участка пересекает местоположение границы земельного участка ответчика.

Основываясь на вышеизложенном, истец просил суд признать недействительным результат кадастровых работ в отношении земельного участка ответчика в виде межевого плана, подготовленного кадастровым инженером 3., в соответствии с которым были проведены работы по уточнению местоположения границы и площади земельного участка; исключить из государственного кадастра недвижимости сведения о местоположении границы земельного участка ответчика, внесенных на основании межевого плана, подготовленного кадастровым инженером 3.

По результатам рассмотрения заявленных требований Муезерским районным судом Республики Карелия было постановлено решение от 27 февраля 2017 года, которым истцу было отказано в удовлетворении его требований в полном объеме [Апелляционное определение Верховного суда Республики Карелия от 19.05.2017 по делу № 33-1743/2017].

В ходе рассмотрения указанного гражданского дела судом было установлено, что ответчикам О. и Ф. на праве общей долевой собственности принадлежит земельный участок, категория земель - земли населенных пунктов, разрешенное использование - для среднеэтажной жилой застройки. Размер долей ответчиков в праве общей долевой собственности на указанный земельный участок пропорционален размеру общих площадей принадлежащих ответчикам квартир в жилом доме, расположенном на данном земельном участке. При этом сведения об указанном земельном участке были внесены в 
ЕГРН, границы земельного участка установлены по результатам проведения кадастровых работ в связи с уточнением местоположения границ земельного участка. Соответствующие сведения в отношении земельного участка, принадлежащего ответчикам О. и Ф., внесены в ЕГРН на основании межевого плана, подготовленного кадастровым инженером 3., являющимся сотрудником филиала ФГУП «Ростехинвентаризация - Федеральное БТИ» по Республике Карелия.

Также судом было установлено, что истец Ч.В. является собственником здания дома связи, а, право собственности на указанное здание признано за истцом решением Муезерского районного суда Республики Карелия на основании положений ст. 237 Гражданского кодекса РФ в силу приобретательской давности. Право собственности истца Ч.В. на здание дома связи зарегистрировано в ЕГРН.

Между тем, суд в решении указал, что земельный участок, находящийся под принадлежащем истцу зданием, не формировался, сведения о нем в ЕГРН не внесены. Данное обстоятельство истцом не оспаривалось.

Установив, что истец не является титульным землепользователем в отношении земельного участка, на котором расположено принадлежащее ему здание дома связи, в то время как он обратился в суд, указывая на нарушение его прав при проведении кадастровых работ по уточнению местоположения границ и площади земельного участка, принадлежащего ответчикам, суд отказал в удовлетворении исковых требований, сославшись на то, что истцом Ч.В. не доказан факт нарушения его прав оспариваемыми результатами кадастровых работ и сведениями, содержащимися в ЕГРН.

Истец Ч.В., не согласившись с вынесенным судом решением, подал апелляционную жалобу, в которой просил решение Муезерского районного суда Республики Карелия от 27 февраля 2017 года отменить и постановить по делу новое решение, которым удовлетворить заявленные исковые требования в полном объеме.

Судебная коллегия по гражданским делам Верховного Суда Республики Карелия, рассмотрев апелляционную жалобу истца Ч.В., отказала в ее удовлетворении и оставила без изменения решение суда первой инстанции, указав следующее.

В п. 45 Постановления Пленума Верховного Суда РФ № 10, Пленума ВАС РФ № 22 от 29 апре- ля 2010 г. «О некоторых вопросах, возникающих в судебной практике при разрешении споров, связанных с защитой права собственности и других вещных прав» разъяснено, что применяя статью 304 ГК РФ, в силу которой собственник может требовать устранения всяких нарушений его права, хотя бы эти нарушения и не были соединены с лишением владения, судам необходимо учитывать следующее.

В силу статей 304, 305 ГК РФ иск об устранении нарушений права, не связанных с лишением владения, подлежит удовлетворению в случае, если истец докажет, что он является собственником или лицом, владеющим имуществом по основанию, предусмотренному законом или договором, и что действиями ответчика, не связанными с лишением владения, нарушается его право собственности или законное владение.

Такой иск подлежит удовлетворению и в том случае, когда истец докажет, что имеется реальная угроза нарушения его права собственности или законного владения со стороны ответчика.

Иск об устранении нарушений права, не связанных с лишением владения, подлежит удовлетворению независимо от того, на своем или чужом земельном участке либо ином объекте недвижимости ответчик совершает действия (бездействие), нарушающие право истца.

Исходя из предмета заявленных Ч.В. исковых требований, обстоятельствами, имеющими значение для правильного разрешения дела, является установление факта владения истцом земельным участком под зданием дома связи на праве собственности или по иному основанию, предусмотренному законом или договором; установление факта нарушения прав и законных интересов истца при проведении кадастровых работ и в результате внесения в государственный кадастр недвижимости сведений о местоположении границ земельного участка, находящегося в собственности ответчиков О. и Ф., в том числе, установление того обстоятельства, имеется ли наложение границ земельных участков сторон настоящего спора по данным ЕГРН.

Учитывая, что земельный участок под принадлежащим истцу зданием дома связи не формировался, на учтен в ЕГРН, а, значит, не существует как объект гражданских прав, в установленном законом порядке в собственность или пользование истцу не предоставлен, судебная коллегия пришла к выводу о том, что в настоящем случае отсутствует право истца, подле- 
жащее судебной защите.

Приведенный пример из судебной практики подтверждает указанное выше утверждение о том, что с негаторными требованиями вправе обращаться в суд только собственник и титульный владелец индивидуально-определенной вещи.

Ответчиком при рассмотрении судом дела, возбужденного на основании негаторного иска, может выступать только то лицо, которое совершило противоправное действие в отношении имущества истца, повлекшее нарушение права собственности.

Данное условие применения негаторного иска как одного из гражданско-правовых способов защиты нарушенного права собственности на землю можно подтвердить примером из судебной практики.

Департамент управления имуществом г.о. Самара обратился в Железнодорожный районный суд г. Самары с иском к К.А. об освобождении земельного участка и взыскании неосновательного обогащения.

Заявленные требования истец мотивировал тем, что ответчик К.А. был привлечен к административной ответственности за самовольное занятие земельного участка. Согласно материалам административного дела К.А. использует земельный участок, находящийся в муниципальной собственности, под размещение гаража без оформления в установленном порядке документов. При этом договор аренды земельного участка до настоящего времени не заключен.

Основываясь на изложенных обстоятельствах, истец просил суд обязать К.А. освободить путем демонтажа гаража земельный участок, площадью 18,0 кв.м, находящийся в муниципальной собственности, и взыскать с ответчика в пользу департамента сумму неосновательного обогащения за пользование указанным земельным участком.

В процессе рассмотрения заявленных департаментом управления имуществом г.о. Самара исковых требований об освобождении земельного участка и взыскании неосновательного обогащения, суд первой инстанции установил, что спорный гараж не принадлежит ответчику K.А., а находится в собственности иного лица, а, ответчик К.А. на протяжении определенного периода арендовал данный гараж у собственника. Именно в то время, когда ответчик арендовал гараж у собственника, он и был привлечен к ад- министративной ответственности на основании постановления заместителя главного государственного инспектора в Самарской области по использованию и охране земель, начальника отдела государственного земельного надзора Управления Росреестра по Самарской области от 23.12.2015 года, за самовольное занятие земельного участка, в связи с чем, ему было назначено административное наказание в виде административного штрафа.

Располагая информацией о том, что ответчик К.А. был привлечен к административной ответственности за самовольное занятие земельного участка, находящегося в муниципальной собственности, департамент управления имуществом г.о. Самара обратился в суд именно к К.А. с требованиями о демонтаже данного гаража.

Однако, в связи с тем, что ответчик К.А. не является собственником данного строения, его не возводил, а лишь пользовался им на протяжении определенного периода, он является ненадлежащим ответчиком по указанному гражданскому делу, с чем также согласилась судебная коллегия по гражданским делам Самарского областного суда в ходе рассмотрения апелляционной жалобы департамента управления имуществом г.о. Самара на решение суда первой инстанции, которым департаменту отказано в удовлетворении исковых требований [Апелляционное определение Самарского областного суда от 16.05.2018 по делу № 33-5755/2018].

В апелляционном определении указано, что наличие постановления от 23.12.2015 года о привлечении ответчика К.А. к административной ответственности за самовольное занятие земельного участка не является достаточным доказательством того, что ответчик является лицом, осуществившим постройку спорного гаража, поскольку доказательств строительства, владения и использования спорного гаража ответчиком, суду не представлено.

Таким образом, как указывает судебная коллегия, наличие постановления от 23.12.2015 года о привлечении ответчика К.А. к административной ответственности, при отсутствии доказательств принадлежности ему гаража на каком-либо праве, не может являться достаточным основанием для возложения обязанности по демонтажу гаража.

С учетом изложенного, судебная коллегия пришла к выводу, что требования об освобож- 
дении самовольно занятого земельного участка и взыскании неосновательного обогащения предъявлены к ненадлежащему ответчику, в связи с чем, отказ в удовлетворении исковых требований департаменту управления имуществом г.о. Самара является обоснованным.

Рассмотренный пример из судебной практики свидетельствует о том, что надлежащим ответчиком по негаторному иску может быть только то лицо, которое фактически нарушило своими противоправными действиями (бездействием) права собственности владельца.

Отдельно необходимо отметить противоправность поведения лица, которое своими действиями (бездействием) нарушило право собственности истца, поскольку предъявление негаторного иска невозможно, если вмешательство в право собственности является правомерным. Восстановление нарушенного в таком случае права собственности возможно в рамках того правоотношения, в котором непосредственно собственник предоставил воздействующему такое правомочие.

При этом правонарушение совершается не только в форме физического активного действия, но и в форме бездействия, то есть когда бездействующий обязан был совершить какие-либо действия, которые бы предотвратили нарушение права собственности истца, но не совершил таковых.

Таким образом, обращаясь в суд за защитой нарушенного права путем предъявления негаторного требования, истец обязан предоставить суду доказательства в подтверждение имеющегося у него права собственности. Поскольку право собственности на недвижимое имущество, в соответствии с нормами действующего гражданского законодательства, подлежит обязательной государственной регистрации в органах росреестра, истец в качестве доказательства зарегистрированного за ним права собственности на объект недвижимости может представить в материалы дела выписку из ЕГРН или свидетельство о государственной регистрации права [2, ст. 131,3 , с. 1$]$.

Помимо обязанности доказать наличие имеющегося у него права собственности истец также должен предоставить доказательства в подтверждение доводов о нарушении принадлежащего ему права собственности на индивидуально-определенную вещь, поскольку в качестве предмета негаторного иска выступают исковые требования об устранении нарушений, не связанных с лишением владения.

Зачастую такие нарушения выражаются, например, в том, что собственник или владелец смежного с принадлежащим истцу земельным участком возвел на данном участке строение с нарушением градостроительных норм, что повлекло нарушение прав истца на пользование своим участком, поскольку возведенное строение препятствует доступу света в окна истца, или в результате возведенного строения были смещены границы земельных участков, что привело к уменьшению площади участка истца.

На рассмотрении Оренбургского областного суда находилось гражданское дело по апелляционной жалобе истца Г. на решение Абдулинского районного суда Оренбургской области от 22.11.2017 года, которым истцу Г. отказано в удовлетворении заявленных им требований о запрете ответчику А. содержать домашнюю птицу в хозяйственной постройке под литером Г6, расположенной напротив квартиры истца, обязании ответчика не чинить препятствий в откачке грунтовых вод из погреба квартиры истца и взыскании компенсации морального вреда [Апелляционное определение Оренбургского областного суда от 22.02.2018 по делу № 33-1089/2018].

Из апелляционного определения судебной коллегии по гражданским делам Оренбургского областного суда следует, что истец Г. обращаясь в суд с перечисленными требованиями, ссылался на то, что в жилом двухквартирном доме одна квартира принадлежит истцу Г., а другая - ответчику А. При этом в самовольно возведенном пристрое к сараю ответчик разводит домашнюю птицу. Однако, рассмотрение от сарая до дома истца составляет менее 10 метров. От сарая исходит неприятный запах, птица заходит на территорию земельного участка, принадлежащего истцу, разносит помет по его территории. Ответчик специального ограждения для домашней птицы не возводит.

Также истец указывал на то, что ответчика А. препятствует ему производить откачивание грунтовых вод, которые собираются в течение дня в погребе истца.

Рассмотрев заявленные исковые требования, суд первой инстанции пришел к выводу об отсутствии правовых оснований для их удовлетворения, указав на то, что доказательств нарушения прав истца по пользованию принадлежащим ему земельным участком действиями ответчика 
не представлено.

Судебная коллегия, не согласившись в части с данными выводами суда первой инстанции, указала следующее.

Отсутствие выгульной площадки не подтверждает того обстоятельства, что птицы А. попадают на земельный участок истца, поскольку из материалов дела следует, что домашняя птица имеется не только в хозяйстве у А., но и у других соседей Г., и доказательств того, что именно домашняя птица А. попадает на земельный участок Г. в материалы дела не представлено. Требование об оборудовании выгульной площадки истцом не заявлялось.

Соглашаясь с указанными выводами суда, судебная коллегия указала, что из имеющегося в материалах дела плана земельных участков усматривается, что расстояние от постройки Г6, в которой содержится домашняя птица, до жилого дома истца составляет 11,9 метров, что значительно меньше допустимых 15 метров и свидетельствует о нарушении ответчиком Правил благоустройства территории муниципального образования Абдулинский городской округ Оренбургской области.

Основываясь на указанных обстоятельствах, учитывая положения ч. 1 ст. 2 Федерального закона от 30.03.1999 № 52-ФЗ (ред. от 29.07.2017) «О санитарно-эпидемиологическом благополучии населения», в которой указано, что санитарно-эпидемиологическое благополучие населения обеспечивается посредством выполнения санитарно-противоэпидемических (профилактических) мероприятий и обязательного соблюдения гражданами, индивидуальными предпринимателями и юридическими лицами санитарных правил как составной части осуществляемой ими деятельности, а также Ветеринарные правила содержания птиц на личных подворьях граждан и птицеводческих хозяйствах открытого типа, которые были утверждены Приказом Минсельхоза РФ от 03.04.2006 № 103 в целях повышения эффективности борьбы с гриппом птиц, положения п. 46 Постановления Пленума № 10/22 в котором указано, что при рассмотрении исков об устранении нарушений права, не связанных с лишением владения, путем возведения ответчиком здания, строения, сооружения суд устанавливает факт соблюдения градостроительных и строительных норм и правил при строительстве соответствующего объекта, судебная коллегия в апелляционном определе- нии указала, что размещением домашней птицы с нарушением допустимого расстояния до жилого помещения, в котором проживает истец, фактически нарушается его право на благоприятную санитарно-эпидемиологическую обстановку, в связи с чем удовлетворила требования истца о запрещении ответчику размещать домашнюю птицу в хозяйственной постройке литер Г6, и отменила в указанной части решение суда, постановив новое об удовлетворении данных требований.

Сложившаяся по данному вопросу судебная практика свидетельствует о том, что для удовлетворения заявленного негаторного требования истец в обязательном порядке должен доказать, что его право собственности при использовании принадлежащего ему имущества нарушены действиями ответчика, и при этом данные нарушения не связаны с лишением владения.

Следует указать, что негаторный иск может быть заявлен также и на основании противоправного бездействия лица, нарушающего право собственности истца в отношении принадлежащего ему земельного участка. Например, в том случае, если собственник соседнего земельного участка производит на своем земельном участке ремонтные работы жилого дома, а оборудование, которым производятся работы, загрязняет земельный участок, принадлежащий истцу.

Помимо вышеперечисленных примеров нарушения прав собственника или титульного владельца в отношении земельного участка в ходе реализации собственником принадлежащего ему права на землю, может возникнуть реальная угроза нарушения права собственности со стороны третьего лица.

Так истец А. обратился в суд с иском к Х. об обязании устранить препятствия в пользовании принадлежащим ему земельным участком, мотивируя тем, что ответчик, являющийся собственником смежного земельного участка, возвел на своем участке двухэтажный гостевой дом и одноэтажную хозяйственную постройку с нарушением СНиПов, в результате чего истец не может беспрепятственно пользоваться принадлежащим ему земельным участком, поскольку существует реальная угроза схода снега с крыш построек ответчика на участок истца, что вызывает трудности в использовании сооружений, возведенных истцом на принадлежащем ему земельном участке и создает угрозу жизни и здо- 
ровью истца и членов его семьи.

Рассмотрев заявленные требования, Всеволжский городской суда Ленинградской области постановил решение от 27.02.2018, которым обязал ответчика Х. установить снегозадерживающие устройства на крышах, принадлежащих ему строений - гостевого дома и хозяйственного блока [Апелляционное определение Ленинградского областного суда от 04.07.2018 № 33-4317/2018].

Ответчик Х., не согласившись с вынесенным судом решением, подал апелляционную жалобу, в которой просит решение Всеволжского городского суда Ленинградской области от 27.02.2018 отменить и принять по делу новый судебный акт, которым отказать в удовлетворении заявленных исковых требований в полном объеме, ссылаясь на отсутствие доказательств наличия реальной угрозы схода снега с крыш его построек на постройки, возведенные на земельном участке истца.

Судебная коллегия по гражданским делам Ленинградского областного суда, учитывая выводы, содержащиеся в экспертном заключении, составленном экспертом АНО «Центр судебной экспертизы «ПетроЭксперт» по результатам проведения судебной строительно-технической экспертизы, о том, что с учетом высоты построек, расстояния построек до смежной границы участков, отсутствия снегозадерживающих устройств на кровле гостевого дома и хозяйственного блока, сход снега на земельный участок, принадлежащий истцу, с технической точки зрения возможен, согласилась с решением суда первой инстанции и указала, что суд пришел к законному и обоснованному выводу о нарушении прав истца, являющегося собственником смежного земельного участка с принадлежащим ответчику земельным участком, на беспрепятственное использование своего земельного участка в зимний период в результате отсутствия снегозадерживающих устройств на кровлях гостевого дома и хозяйственного блока, возведенных ответчиком.

Приведенный пример отчетливо показывает, что негаторный иск можно применить и в том случае, если имеется только потенциальная угроза нарушения права собственности.

Вместе с тем, в указанном случае необходимо учесть положения ст. 1065 ГК РФ, в соответствии с которыми в гражданском законодательстве предусмотрен специальный, так называемый превентивный иск, который направлен на пре- дотвращение причинения вреда. Таким образом, истец может обратиться в суд с негаторными требованиями в соответствии со ст. 304 ГК РФ и при реальной угрозе нарушения его прав.

Э.М. Мурадьян, исследовавший превентивный иск, определял его как иск, который опережает во времени действия ответчика, оцениваемые истцом как угрожающие его правам, благам и направленный на предотвращение такого акта [4, с. 23]. Также Э.М. Мурадьян давал другое определение превентивному иску и указывал, что это спор о праве, рассматриваемый в суде заблаговременно, с целью осуществления права истца исключить вероятные негативные последствия и предупредить реальные фактические и формально юридические осложнения.

Таким образом, превентивный иск представляет собой такой способ защиты, который опережает во времени неправомерные действия ответчика, в том случае, когда возникает такая угроза.

Если собственнику земельного участка достоверно известно, что в отношении его права возникла реальная угроза его нарушения, он не должен дожидаться того момента, когда угроза превратиться в уже совершенные неправомерные действия, повлекшие негативные последствия, он должен обладать юридически закрепленной возможностью предупредить возможное нарушение принадлежащего ему права посредством обращения в суд с соответствующими требованиями.

Следовательно, превентивный иск является разновидностью негаторного иска и может быть использован именно для предупреждения возможного правонарушения в ходе реализации собственником своих прав на землю.

Вышеизложенное позволяет прийти к выводу, что при подаче негаторного иска собственник земельного участка может заявлять требования об обязании ответчика, нарушившего права истца на владение и пользование землей, совершить действия по устранению допущенных им нарушений; требования об обязании прекратить совершать действия, приводящие к нарушению прав истца в отношении его земли, а также требования о пресечении действий, которые впоследствии могут создать препятствия истцу, являющемуся собственником земельного участка, или иному титульному владельцу в пользовании принадлежащим ему имуществом.

При этом, обращаясь в суд с негаторным ис- 
ком, истцу, чье право на земельный участок нарушено, следует учесть, что для его удовлетворения необходимо наличие четырех основных условий:

1) факт наличия у истца права собственности на земельный участок, в отношении которого совершено противоправное деяние;

2) факт нахождения земельного участка именно во владении лица, обратившегося в суд с негаторными требованиями;

3) противоправные действия, либо бездействия совершены именно лицом, привлеченным к участию в судебном разбирательстве в качестве ответчика, и создают препятртвия в осуществлении полномочий собственника земли;

4) отсутствие каких-либо договорных и иных обязательственных отношений между сторонами.

Поскольку объектом требований по негаторному иску является устранение длящегося правонарушения, которое сохраняется к моменту обращения с данным иском к суд, срок исковой давности к данным требованиям не применим, и негаторный иск может быть заявлен в суд собственником или титульным владельцем земли, чье право было нарушено, в любой момент, пока указанное правонарушение сохраняется.

Удовлетворяя негаторное требование, суд может запретить ответчику совершать опреде- ленные действия, либо обязать ответчика совершить действия по устранению последствий правонарушения, которое им было совершено.

Необходимо указать, что, несмотря на высказанное в литературе мнение об отнесении таких исков, как: иск о признании вещного права, иск об установлении границ земельного участка; иск об установлении сервитута; иск об исправлении кадастровой ошибки; иск об освобождении имущества от ареста и иск о признании права отсутствующим, к негаторным, перечисленные иски являются разновидностью такого способа защиты нарушенного права, как признание права. Большинство данных исков может быть заявлено и невладеющим собственником, в то время как одним из основных условий для предъявления негаторного иска в суд является факт наличия у собственника той вещи, в отношении которой ответчиком было совершено противоправное деяние, повлекшее нарушение прав истца.

Таким образом, негаторный иск при защите права собственности на землю представляет собой требование владеющего земельным участком собственника или титульного владельца к лицу, нарушившему права собственности истца, об устранении чинимых им препятствий в осуществлении правомочий владения, пользования и распоряжения землей.

\section{Библиографический список}

1. Подшивалов Т.П. Негаторная защита интересов собственников смежных земельных участков // Законы России: опыт, анализ, практика. 2016. № 12. С. 49-53.

2. «Гражданский кодекс Российской Федерации (часть первая)» от 30.11.1994 № 51-Ф3 (ред. от 03.08.2018) (с изм. и доп., вступ. в силу с 01.09.2018). СПС КонсультантПлюс.

3. Федеральный закон от 13.07.2015 № 218-ФЗ (ред. от 03.08.2018) «О государственной регистрации недвижимости» (с изм. и доп., вступ. в силу с 01.10.2018). СПС КонсультантПлюс.

4. Мурадьян Э.М. Превентивные иски // Государство и право. 2001. № 4. С. 23-27.

5. Апелляционное определение Верховного суда Республики Карелия от 19.05.2017 по делу № 33-1743/2017. СПС КонсультантПлюс.

6. Апелляционное определение Самарского областного суда от 16.05.2018 по делу № 33-5755/2018. СПС КонсультантПлюс.

7. Апелляционное определение Оренбургского областного суда от 22.02.2018 по делу № 33-1089/2018. СПС КонсультантПлюс.

8. Апелляционное определение Ленинградского областного суда от 04.07.2018 № 33-4317/2018. СПС КонсультантПлюс. 